Vol. 7, No. 1, 2021

UDC 711.424

Viktoria Taras

\title{
ARCHITECTURAL WORKS OF PIERRE RICAUD DE TIRREGAILLE IN GALICIA
}

\author{
Senior scientist \\ Institute of Ethnology of NAS of Ukraine, Lviv \\ e-mail: vikitaras@yahoo.com \\ orcid: 0000-0002-9144-8331
}

Received: 15.12.2020 / Revised: 27.03.2021 / Accepted: 07.04.2021

(C) Taras V., 2020

https://doi.org/10.23939/as2021.01.096

Astract. The article analyzes the life and creative path of the French military engineer, geometer and architect Pierre Rico de Tiregail (1725 - after 1772).

Key words: architect, Pierre Ricaud de Tirregaille, palace, garden.

\section{Problem statement}

Art history, historical and architectural studios contain selective and incomplete information about the life and work of architect Pierre Rico de Tirregail. Little information has been preserved about its activities, most of the documents and drawings are scattered in archival funds of different countries, some of them do not have the author's signature. The analysis of archival materials and scientific publications made it possible to show the diversity of the architect's work.

\section{Purpose of the article}

The article aims to highlight the life and creative path of architect Pierre Rico de Tirregail.

\section{Analysis of recent research and publications}

Generalization and systematization of the results of previous studies showed that scientific research on a given topic was carried out in several directions. The first direction includes those studies of the authors, which are devoted to the personality of the architect Pierre Rico de Tirregail and which can be divided into works concerning biographical information about the architect, and studios about various projects that Pierre Rico de Tirregail completed to order.

Some biographical information about Pierre Rico de Tirregail can be obtained from the bibliographic publication "Dictionary of Polish architects and builders, as well as foreigners working in Poland”, which was created by Stanislaw Loza (1888-1956) (Loza S., 1931, S. 286) in 1917, from the 
"General Encyclopedia of Fine Arts from antiquity to the present", which was founded by Ulrich Tim and Felix Becker (Stephens-Theodotos E. A., 1938), from the "Polish Biographical Dictionary" (1988-1989) (Kowalczyk J., 1977, S. 270-272). E. Zhylko's doctoral dissertation is devoted to the patronage of the crown Hetman Jan Clement Branytsky regarding artists, including the architect Pierre Rico de Tirregail (Żyłko E., 1955). Research By M. Moreliovskyi (Morelowski M., 1959, S. 351) and Z. Hornung (Hornung Z., 1959, S. 276-284) focus on the artist's French origin. The research of Ye. Kovalchyk (Kowalczyk J., 1988, S. 299-317; 19, S. 99-114) highlights the architectural activities of Pierre Rico de Tirregail in Warsaw. Articles in the "Hall encyclopedia" (Ricaud de Tirregaille P., 1867, S. 297-298), as well as the research of B. Olshevich (Olszewicz B., 1932, S. 205-206), E. Kovalchik (Kowalczyk J., 1977, S. 53-59) and D. Kosachki (Kosacka D., 1970, S. 29, 54-55) show Pierre Rico de Tirregail as the compiler of the map of Warsaw in 1762.

The second direction of research includes the works of T. Mankovskyi (Mańkowski T., 1932, S. 110-113; 25, S. 391-433), Ye. Kovalchyk (Kovalchyk Ye., 1991, P. 51, 55, 62), E. Sveykovskyi, Ya. Chernetskyi (Czernecki J., 1939, S. 42-52, 413-429), Ya. Ross (Ross J., 1970, S. 42-52, 413-429), H. Hrynyk, O. Yarosh-Zamoyska (Hrynyk H., 2000, S. 256), which relate to the issues of local history and the history of architecture. They focus on the personality of the customer and the architectural and planning solution of structures designed and built by Pierre Rico de Tirregail.

A separate area of research includes works on landscape art by H. Tsiolek (Ciołek G., Plapis W., 1986, S. 96-102), Ya. Bohdanovskyi (Bogdanowski J., 2000, S. 61, 64, 77, 84, 258), L. Maydetskyi (Majdecki L., 2008, S. 61, 64, 77, 84, 258), in which Pierre Rico de Tiregail appears as a specialist in the design and laying of gardens.

Important sources for finding out bibliographic information about Pierre Rico de Tiregail and his project orders are handwritten and graphic materials that are stored in the archives of Warsaw (Archiwum Główne Akt Dawnych w Warszawie), Krakow (Archiwum Narodowe w Krakowie), The National Institute of heritage in Warsaw (Narodowy Instytut Dziedzictwa w Warszawie) and the National Library of France in Paris.

\section{Results and discussion}

Even though the figure of this military engineer, geometer, architect Pierre Ricaud de Tirregaille (1725-1772) is relatively well known to researchers, his biography, outside the period of activity in the Polish-Lithuanian Commonwealth, remains largely unknown.

Pierre Rico de Tiregaille was born around 1725 in a French noble family in the Tiregaille area in Provence, where his parents owned property. It is known that for some time he travelled around Europe. From the remained correspondence, we learn that before arriving in the Polish-Lithuanian Commonwealth, he was in Spain for some time (Archiwum Główne Akt Dawnych w Warszawie, S. 553), where he improved his professional education in Barcelona under the guidance of his relative, engineer Francis Rico de Tiregail. The Polish researcher Ye. Kowalczyk in the twelve-year activity of Pierre Rico de Tirregail in the Polish - Lithuanian Commonwealth separated three periods: I - Warsaw (1752-1757), II - Lviv (1757-1760) and III - Warsaw (1760-1762). Most of the assignments that the architect received during his work in the Polish-Lithuanian Commonwealth came from several magnate families: Branitski, Potocki, Mnishiv, etc.

The first mention of Pierre Rico de Tiregail's stay in the Polish-Lithuanian Commonwealth dates back to 1752 when he received the rank of lieutenant in the infantry regiment of the grand crown hetman Jan Clement Branytsky (1689-1771) and as a military engineer entered the service. In 1753, he was promoted to captain, and on November 11, 1753, in Warsaw, he married Barbara Cieciewiczówna (Narodowy Instytut Dziedzictwa w Warszawie, Teka 320. - S. 162. - 1753 r.), the daughter of Antoni, a 
city writer from Old Warsaw, and later three children were born in the family. In addition to his military salary, Pierre Rico de Tirregail receives a fixed salary of 200 ducats per year from hetman Jan Branycky, who hires him as an engineer at his residence in Bialystok 1753-1757. However, Pierre Rico de Tiregail does not move to Bialystok but stays in Warsaw, where he also receives other orders. For four years, he visited the residence in Bialystok only during the spring and summer season, he was entrusted with the development and management of installation works for the water supply of the garden and menagerie using hydraulic devices that were supposed to provide water to fountains, cascades, channels and ponds (Fig. 1) (Narodowy Instytut Dziedzictwa w Warszawie, Teka 320. - S. S. 1-2; Teka 353. - S. 1; Teka 358. - S. 25, $29,33,38,39)$.

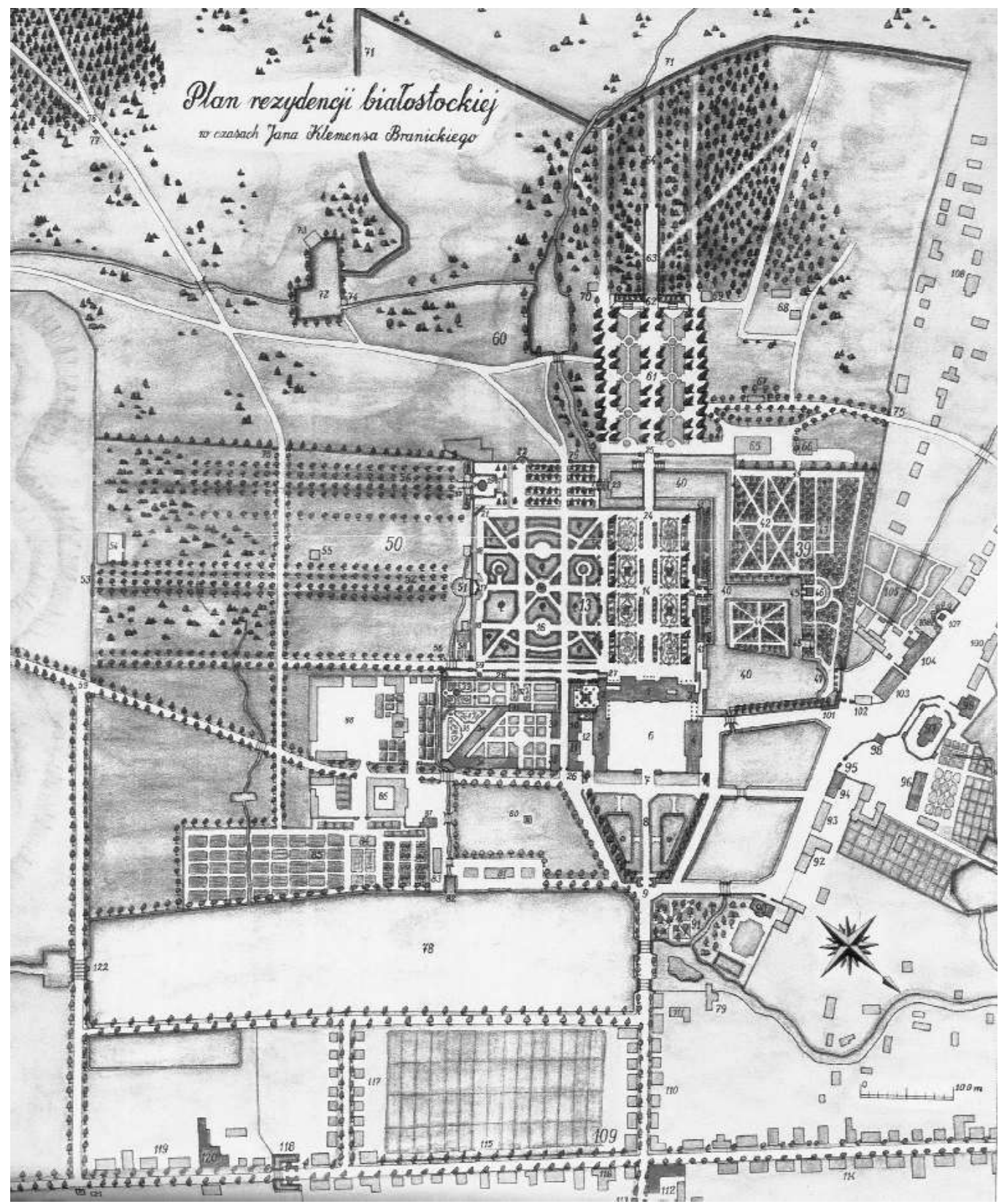

Fig. 1. Bialystok. Plan of hetman Branitsky's residence

For two years in a row (1752-1754), Pierre Rico de Tiregaille teaches a student, the son of Casper Duchesne, presumably an architect of French origin, and makes him a protégé with Branytsky in Bialystok 
(Narodowy Instytut Dziedzictwa w Warszawie, S. 176. 1754). Hetman Branytsky called Pierre Rico de Tirregail "my engineer" (Narodowy Instytut Dziedzictwa w Warszawie, S. 142a, 143, 159 -162, 176, 208, 214, 216, 217, 220, 221), obviously, he also helped the hetman with his architectural and design knowledge, at least with advice. The architect criticized the main ideas of hetman artists in the residence in Bialystok, which served as a source of conflict between Pierre Rik de Tirregail and the chief architect of hetman Branytsky, colonel Jan Henrik Klemm. In 1754 Tiregail faces a" far-fetched" conflict over the timing of completion of water deposits in the gardens of Bialystok (Narodowy Instytut Dziedzictwa w Warszawie, Teka 341. P. 8. 1754). According to Kurdwanowski, in a conversation with Pierre Rico de Tirregail, he tried to encourage him to complete the work as soon as possible, but he still had doubts about the engineer's assurances (Narodowy Instytut Dziedzictwa w Warszawie, Teka 341. P. 8. 1754). This situation caused dissatisfaction with hetman Branytsky, so the works that Pierre Rico de Tiregail was supposed to direct are transferred to another architect Lorenz Peter Christoph, and the hetman expresses his readiness to personally control the laying of pipes (Narodowy Instytut Dziedzictwa w Warszawie, Teka 342. - S. 35, 38, 40, 41). Pierre Rico de Tirregail receives his salary from Branycky on the way from Warsaw to Bialystok (Narodowy Instytut Dziedzictwa w Warszawie, Teka 315. - S. 317). Already in 1755 (Narodowy Instytut Dziedzictwa w Warszawie, Teka 320. S. 222) and 1756 Pierre Rico de Tirregail goes to Bialystok at his own expense (Narodowy Instytut Dziedzictwa w Warszawie, Teka 320. S. 235). In 1757, he received a letter with money from Lieutenant Colonel Klemm, for which he thanked him in a return letter on his behalf and on behalf of his wife (Narodowy Instytut Dziedzictwa w Warszawie, Teka 315. S. 251). This was the last payment. Due to the termination of payments, Pierre Rico de Tirregail turns to Branytsky, reminding him of the previously made promise to pay him money, taking into account family circumstances, until he finds another suitable job (Narodowy Instytut Dziedzictwa w Warszawie, Teka 353. S. 1). In response, hetman Branitsky orders to pay the last salary not personally to Pierre Rico de Tirregail, but to his creditor, colonel Hiche (Narodowy Instytut Dziedzictwa w Warszawie, Teka 315. S. 248.1758 r.). At the beginning of 1758, Pierre Rico de Tiregaille was dismissed from the service of Branycky. Yan Henrik Klemm complains that after the release of Pierre Rico de Tirregail, he is deprived of the "Astrolabia", a book on architecture and projects, including plans of the palace and garden in Horosh and numerous drawings that he borrowed from the library of hetman Branitsky (Narodowy Instytut Dziedzictwa w Warszawie, Teka 339. S. 11, 12. 1758).

In 1757, Pierre Rico de Tirregail moved for four years from Warsaw to Lviv, where he carried out several architectural projects. First, Franciszek Salezia Potocky, voivode of Kyiv, designed and implemented in 1757-1760 a large palace complex with a garden in Kristinopol on the Buh River near Sokal. It is possible that his authorship also belongs to the project of the Potocky Palace in Perespa in 1758 (not preserved). Thus, the art critic V. Vujcyk considered him the author of such a project (Vuytsik V. S., 2003, P. 68), while the Polish researcher Ye. Kowalczyk only assumed such a possibility (Kowalczyk J., 1989, S. 270 - 272). While overseeing work in Christinopol, Pierre Rico de Tiregail takes on the project of the Chatsky-Felinsky Palace on the Galician suburb of Lviv behind the Jesuit gate. According to the Treaty of September 13, 1758, Pierre Tiregail was supposed to work for two years for 10 thousand Polish zlotys. As part of this project, the architect acted not only as a designer, but also as a construction entrepreneur, but in two years he managed to lay only the foundation, so on August 29, 1759, Chatsky filed a complaint against him with the Lviv City Court. In 1759 Pierre Tiregail developed a project to modernize the twostory Palace for the court hunter Anthony Belsky in Lviv near the Galician Gate (Kowalczyk J., 1989, S. 271). Two drawings of facade projects are kept in the National Library in Paris ( Bibliothèque nationale de France. Cabinet des Estampes).

In Lviv, Pierre Rico de Tirregail was a construction adviser to the Greek Catholic Metropolitan of Lviv Leon Sheptytsky, where at that time the royal architect B. Meretin was completing St. George's Cathedral. Remaining a supporter of rococo and classicism, Pierre Rico de Tiregail criticized this structure, 
interpreting the style of St. George's Cathedral as outdated. In response to criticism, B. Meretin filed a lawsuit against the architect on November 3, 1758, for allegedly making unmotivated charges. Such criticism caused the dissatisfaction of Metropolitan Lev Sheptytsky, as a result - he breaks the contract with Pierre Rico de Tiregail and stops using his services because significant funds were collected and spent on construction (Mańkowski T., 1932, S. 209). Volodymyr Vujtsik suggested that the author of the original design of the palace of Greek Catholic Metropolits in Lviv could also be Pierre Rico de Tirregail, and not Clemens Fesinger (Vuytsik V. S., 2003, P. 68).

During the supervision of the construction of the Palace in Christinopol, Pierre Rico de Tirregail was introduced to Ignatius Tsetner (1728-1806), who repeatedly visited the palace, since his wife came from the Potockyi family. The result of this acquaintance was an invitation to develop a Palace project in Krakovets. The plan of the palace, which is kept in the National Library of France in Paris, was fulfilled, according to the assumptions of R. Aftanazi (Aftanazy R., 1996, S. 53-63) and P. Vutrob (Wątroba P., 2016, S. 67-73), it was Pierre Rico de Tiregaille. The author of this article also believes that the baroque garden at the Palace in Krakovec belongs to the authorship of Pierre Rico de Tirregail.

At the beginning of 1760, the crown hetman Branytsky asks Pierre Rico de Tirregail to draw a grain mill of the Bernardines, which was moving with the help of the draft force of oxen and direct a carpenter who was supposed to make a model of this mill, which was to be sent to Mostyska. Besides, Hetman Branytsky asked him to design a mill for the garden as a place for walking. Pierre Rico de Tiregail provides the hetman with samples of similar mills that he came across in Spain (Narodowy Instytut Dziedzictwa w Warszawie, Teka 315. S. 164, 209, 210).

At the end of 1760 Pierre Rico de Tirregail and his family return to Warsaw. At the request of Czech crown marshal Francis Belynsky, who headed the road commission (Komisja Brukowa) founded by King Augustus III, he takes on the ambitious task of drawing up a detailed plan of the city of Warsaw, which eventually brought him fame. On eighteen parts on a scale of about 1:1000, he makes a plan of Warsaw with its suburbs probably based on the measurements of the architect Jakub Fontan (Fig. 2). Pierre Rico de Tirregail completed work on the plan on May 1, 1761, receiving a reward of 2,533.1 zlotys. At the request of F. Belynsky, Pierre Rico de Tirregail is preparing a plan of Warsaw for printing, reducing it to a scale of 1:6690. Under the plan, the architect places a panorama of the city of Warsaw from the Visla River; on top and both sides there are seventeen impressive buildings, mainly palaces - royal and senatorial. After the Second World War, these images became a valuable source for the reconstruction of palaces.

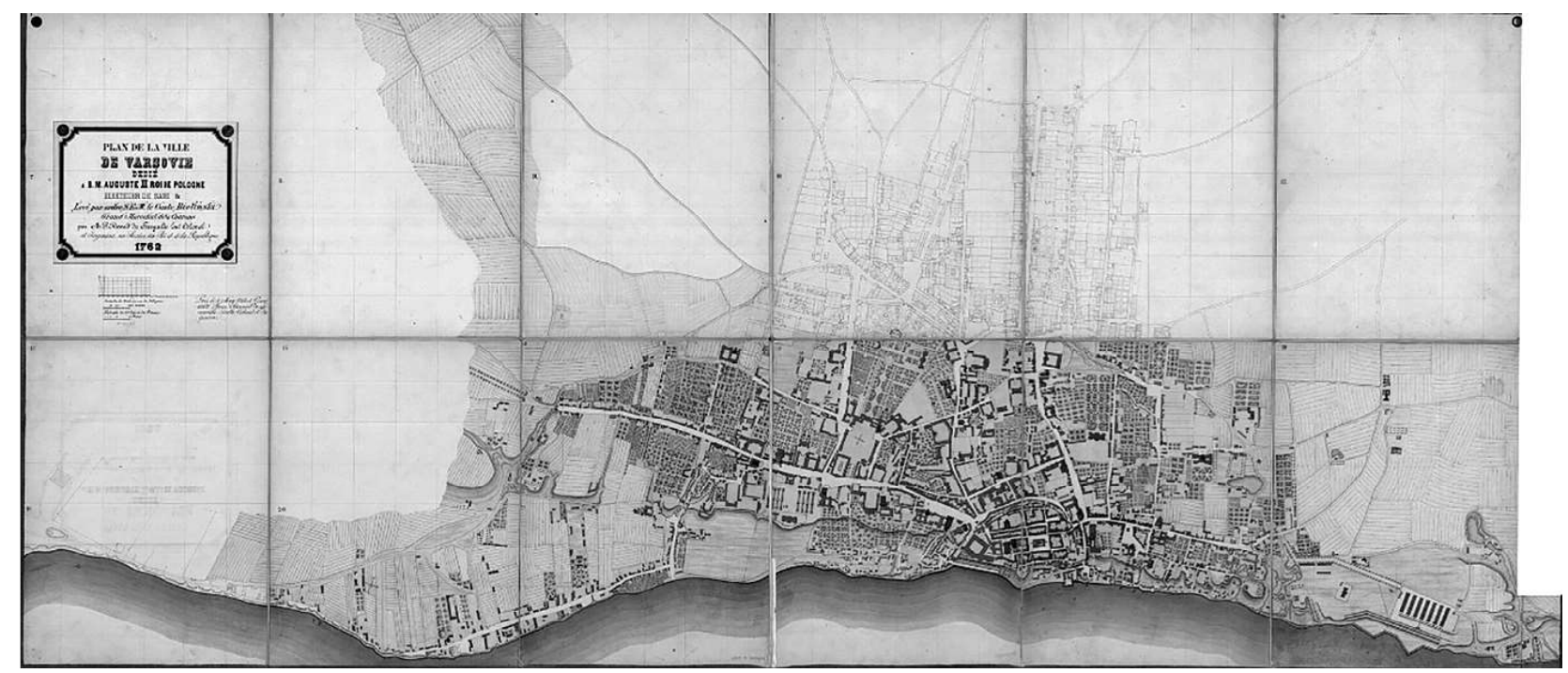

Fig. 2. The Warsaw plan drawn up by architect Pierre Rico de Tiregail. 1761 
As the owner of the graphic plan, Pierre Rico de Tirregail also owned a typographic cliche, which was executed in 1762 on four copper plates by Jakub Teofil Marstalski (Marstaller). Pierre Rico de Tiregail is going to dedicate the developed Warsaw plan to king Augustus III. He offers hetman Branytsky to buy cliches from him (27, Teka 353. S. 2, 3). The plan was published in 1762 under the title "Plan de la Ville de Varsovie Dedie a S.M. Auguste III Roi de Pologne Electeur de Saxe. \& \&. Leve par ordre de S.E.M. Comte Bielinski Grand Marcchal de la Couronne par M.P. Ricaud de Tirregaille Lieut Colonel et Inginieur au Service du Roi et de la Republique en 1762" (Fig. 3). In addition to the Warsaw plan, Pierre Rico de Tiregail planned to release an album with important metropolitan buildings at that time, the National Library in Paris stores his drawings of the Krakow suburb street and the Krasinski Palace [7] in Warsaw with appropriate topographical and historical explanations.

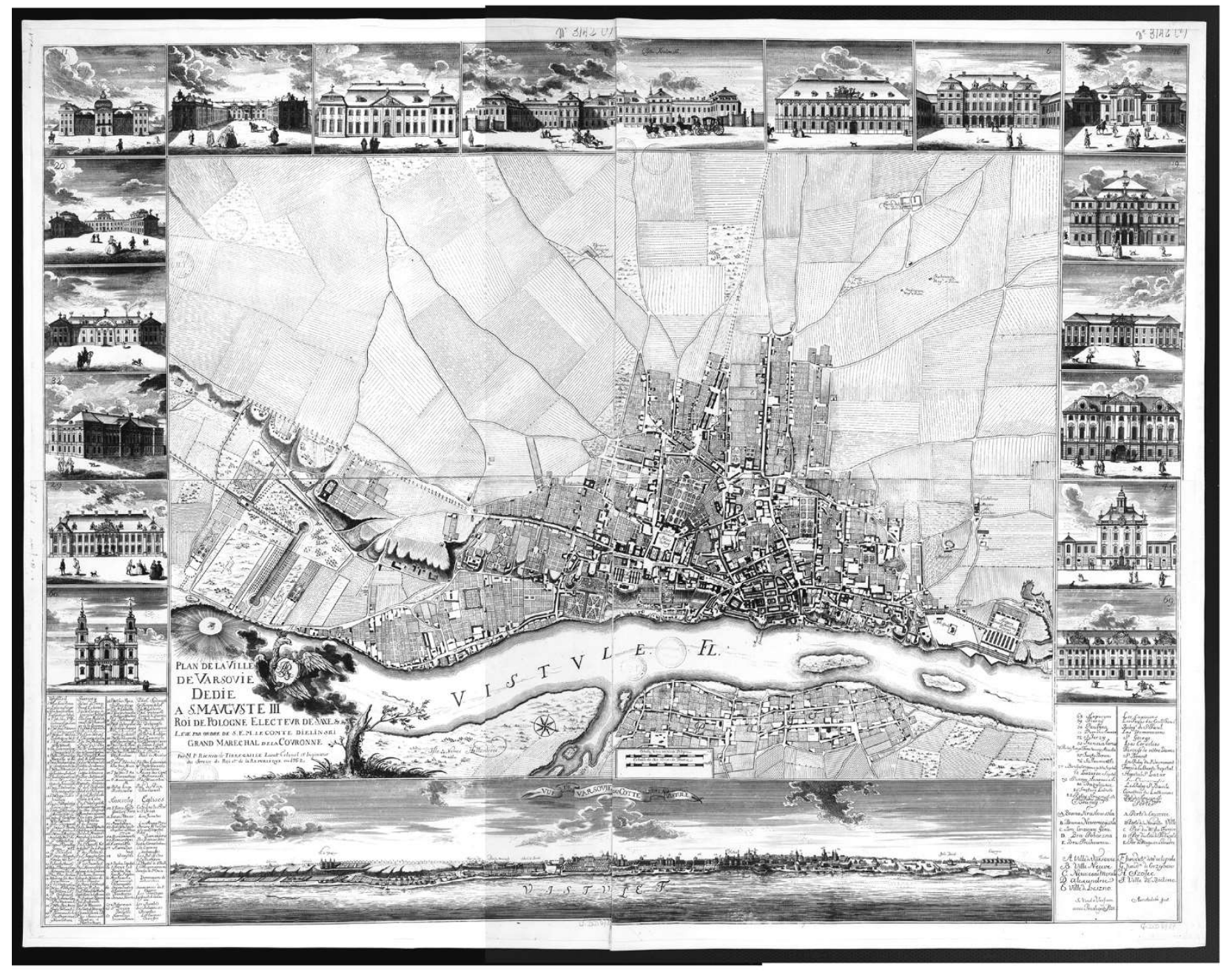

Fig. 3. The Warsaw plan by Pierre Rico de Tiregail.

"Plan de la Ville de Varsovie Dedie a S. M. Auguste III Roi de Pologne Electeur de Saxe.

$\&$ \&. Leve par ordre de S.E.M. Comte Bielinski Grand Marcchal de la Couronne par M. P. Ricaud de Tirregaille Lieut Colonel et Inginieur au Service du Roi et de la Republique en 1762"

After nine years of service, Pierre Rico de Tirregail hoped to get promoted. In December 1761 he asked hetman Branycky to help him advance to the rank of colone. His request was also supported by marshal F. Belinsky, who asked the hetman to help in the Royal Court with this request, which "will give the Warsaw plan more importance" (Narodowy Instytut Dziedzictwa w Warszawie, Teka 
325. S. 226. 1761) but, unfortunately, this did not work. After an eleven-year stay in Poland, Pierre Rico de Tiregaille, unable to hold a corresponding position at the court of Augustus III, moved to Berlin in 1762-1763, where he was assigned to the engineering department for an indefinite position and a teaching position at the court of King Frederick II of Prussia. In 1765, in Potsdam, Rico de Tirregail married Marią Louisą Binius.

Pierre Rico de Tiregail continues to maintain contacts with Poland, and in 1765 he wrote to Isabella Branycka with a request to assist in the purchase by King Stanislaw August of eighty paintings by "the oldest and most famous artists" from the Venetian Baron de Bodissony (Narodowy Instytut Dziedzictwa w Warszawie, Teka 315. S. 291, 292). This transaction took place, and in the same year in Berlin, the architect receives money from hetman Branytsky for mediation in this case (Narodowy Instytut Dziedzictwa w Warszawie, Teka 315. S. 323).

In 1772, in Potsdam, he published a numismatic treatise on Russian medals of the XVIII century. This illustrated work is titled "Médailles sur les principaux événements de l'Empire de Russie, depuis le règne de Pierre le Grand jusqu'à celui de Catherine II. Avec des explications historiques. A Postdam, chés Sommer, 1772" consisted of one hundred and eleven engraved vignettes with a two-sided image and historical explanations of Russian medals minted from the time of Peter I to Catherine II (Fig. 4). In 1776 Pierre Rico de Tiregail receives the rank of colonel and continues to work on the next volume of a numismatic treatise on the medals of the Brandenburg court, but soon he dies.

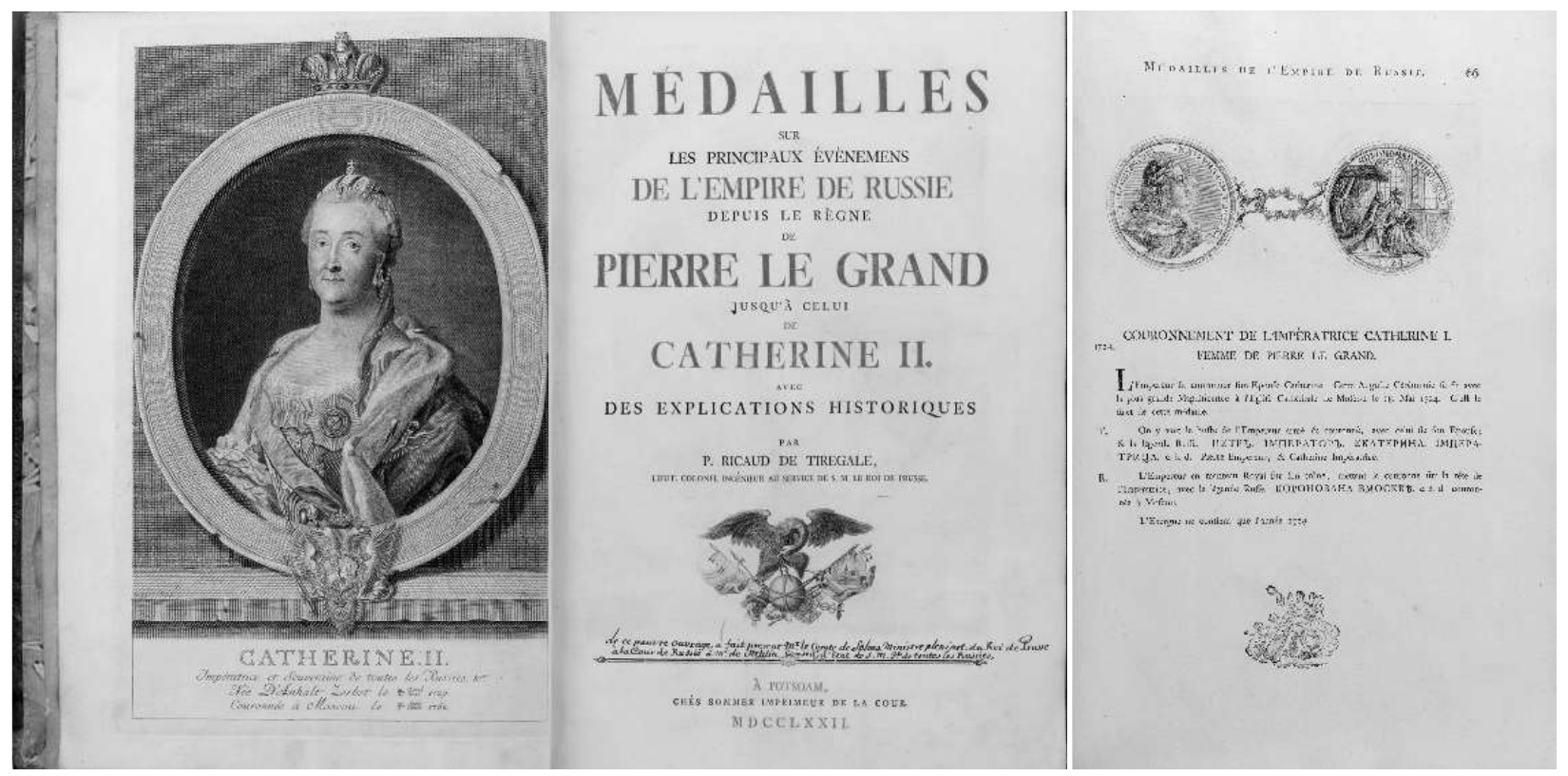

Fig. 4. Numismatic treatise "Médailles sur les principaux événements

de l'Empire de Russie, depuis le règne de Pierre le Grand jusqu'à celui de Catherine II.

Avec des explications historiques. A Postdam, chés Sommer, 1772" published by Pierre Rico de Tirregail

\section{References}

Aftanazy R., 1996. Dzieje rezydencji na dawnych kresach Rzeczypospolitej. Wrocław,Vol. 8: Wojewodztwo ruskie: Ziemia Przemyska i Sanocka. Wyd. 2 uzup.

Allgemeines Lexikon der Bildenden Künstler von der Antike bis zur Gegenwart. Begründet von Ulrich Thieme und Felix Becker. Band 32: Stephens-Theodotos. E. A. Seemann. Leipzig, 1938.

Archiwum Główne Akt Dawnych w Warszawie. Sigillata 27. 
Archiwum Narodowe w Krakowie. Plan pałacu Franciszka Salezego Potockiego wojewody kijowskiego w Krystynopolu oraz pałacyku w Perespie. Archiwum Potockich w Krzeszowic. Sign. 3137. 29/635/0/14/3137.

Archiwum Roskie. Sygn. XVIII/34 (6 листів Р. Тіррегайля до Я. Браніцького від 1. 1752-62), sygn. XXXIV/29 (лист Р. Тіррегайля до Я. Клемма від 1757).

Bibliothèque nationale de France. Cabinet des Estampes. Vc. 350. 4. K-O.

Bibliothèque nationale de France. Département des estampes et de la photographie. Cabinet des Estampes. Vc. 350. T. 7.

Bibliotheque nationale de France. Paris. Pierre Ricaud de Tirregaille. Palais de Cracoviec apparteneant a m. le Cte. Cettner du Cote de l'Entree. Sign. R 14550.

Bogdanowski J., 2000. Polskie ogrody ozdobne. Warszawa : Arkady.

Ciołek G., Plapis W., 1968. Materiały do słownika twórców ogrodów polskich, Warszawa.

Ciołek G., 1954. Ogrody polskie, Warszawa.

Ciołek G., 1955. Zarys historii kompozycji ogrodowej w Polsce. Łodz-Warszawa.

Czernecki J., 1939. Mały król na Rusi i jego stolica Krystynopol. Kraków.

Hornung Z., 1959. Na śladach działalności artystów francuskich w Polsce // Teka Kom. Hist. Sztuki. T. 1.

Kosacka D., 1970. Plany Warszawy XVII i XVIII w. w zbiorach polskich. Katalog. Warszawa.

Kowalczyk J., 1977. Goût français po warszawsku. Warszawskie pałace rokokowe na planie Ricaud de Tirregaille'a // Architektura, R. 31. Nr. 1-2.

Kowalczyk J.1988. Pierre Ricaud de Tirregaille - architekt ogrodów i pałaców // "Kwartalnik Architektury i Urbanistyki”.,Vol. 33. Z. 4.

Ricaud de Tirregaille P., 1867. Encyklopedyja powszechna. Warszawa. T. 25.

Kowalczyk J., 1981. Wędrówka po pałacach rokokowych z panem Ricaud // Jesteśmy w Warszawie. Miasto dawne i nowe. Warszawa : PIW. T. 1.

Kowalczyk J., 1989. Ricaud de Tirregaille Pierre // Polski Słownik Biograficzny. Wrocław-Warszawa-Kraków-Gdańsk-

Łódź : Zakład Narodowy Imienia Ossolińskich, Wydawnictwo Polskiej Akademii Nauk - T. XXXI.

Kriegsarchiv des Österreichischen Staatsarchivs in Wien. Josephinische Landesaufnahme, 1763-1787.

Łoza S., 1931. Architekci i budowniczowie w Polsce / Słownik architektów i budowniczych Polaków oraz cudzoziemców w Polsce pracujących. Wydanie drugie, uzupełnione. Wydawnictwo Kasy im. Mianowskiego, Instytutu Popierania nauki Warszawa, Palac Staszica.

Majdecki L., 2008. Historia Ogrodów. Warszawa : Wydawnictwo naukowe PNW T. 1: Od starożytności po Barok. 419-

Mańkowski T., 1932.Lwowskie kościoły barokowe // Prace sekcyi historyi sztuki i kultury Towarzystwa Nauk we Lwowie T. 2. Zesz. 2.

Mańkowski T., 1948.Architekt Pierre Ricaud de Tirregaille // Rocznik Zakładu Narodowego im. Ossolińskich. T. 3.

Morelowski M., 1959. Pierre Ricaud de Tirregaille // Francastel P. Les architectes célèbres. Paris, T. II.

Narodowy Instytut Dziedzictwa w Warszawie (Ośrodek Dokumentacji Zabytków w Warszawie). - Текі Jana Glinki.

Olszewicz B., 1932. Kartografia polska XVIII wieku // Polski Przegl. Kartogr. R. 10: Nr. 38-39.

Ross J., 1970. Pałacyk w Perespie // Rokoko. Studia nad sztuką 1 połowy XVIII w. Warszawa.

Świeykowski E., 1912.Plany zamku Franciszka Salezego Potockiego wojewody kijowskiego w Krystynopolu nad Bugiem w powiecie sokalskim // Spraw. Kom. do Badań Hist. Sztuki w Polsce. Kraków. T. 8.

Wątroba P., 2016.Le palais d'Ignacy Cetner a Krakowiec Et son architecte Pierre Ricaud de Tirregaille nouvelles constatations et hypotheses // Studia $\mathrm{z}$ historii sztuki ofiarowane profesorowi Janowi Ostrowskiemu, [red. Andrzej Betlej, Katarzyna Brzezina-Scheurer, Agata Dworzak et al.]. Kraków.

Żyłko E., 1955. Mecenat artystyczny Jana Klemensa Branickiego hetmana wielkiego koronnego. Warszawa (mszp. rozprawy doktorskiej).

Hrynyk G., Yarosh-Zamoyska O. Krystynopil, 2000. Chervonohrad, 256 p.

Kovalchyk E., 1991. Late Baroque magnate residences in Volyn and Lviv region // Ukrainian Baroque and European context. Kyiv : Scientific Opinion.

Vuytsyk V. S., 2003.Lviv baroque palaces. Bilsky Palace // Bulletin of the Ukrzahidproektrestavratsiya Institute, No. 13.

Vuytsik V.S Baroque palaces of Lviv. Bilsky Palace // Bulletin of the Institute "Ukrzakhidproektrestravatsiya". 2003. No. 13. 34. Hrynyk G., Yarosh-Zamoyska O. Kristinopol (1692-1951)/ Chervonograd, 2000. 256 p. 35. Kovalchik E. Late Baroque Magnate Residences in Volyn and Lviv // Ukrainian Baroque and European Context. Kiev : Scientific Thought, 1991. 


\section{Вікторія Тарас}

Ст. наук. співробіт.

Інституту народознавства НАН Украӥни, Львів

e-mail: vikitaras@yahoo.com

orcid: 0000-0002-9144-8331

\section{АРХІТЕКТУРНИЙ ДОРОБОК П'ЄРА РІКО ДЕ ТІРРЕГАЙЛЯ В ГАЛИЧИНІ}

Анотація. Незважаючи на те, що постать цього військового інженера, геометра, архітектора П'єра Ріко де Тіррегая (1725-1772) є відносно добре відомою дослідникам, його біографія поза періодом діяльності в Речі Посполитій залишається в основному невідомою. Узагальнення та систематизаиія результатів попередніх досліджень показали, ио наукові дослідження з ијєї теми проводились у кількох напрямках. Перший напрямок включає ті дослідження авторів, щзо присвячені особистості архітектора П'єра Ріко де Тіррегейла і які можна розділити на роботи, шо стосуються біографічної інформаиії про архітектора, та студії про різні проекти, виконані П'єром Ріком де Тіррегейлом на замовлення. Рукописні та графічні матеріали, що зберігаються в архівах Варшави, Кракова, Наиіональному інституті спадщини у Вариаві та Наџіональній бібліотеиі Франиії в Парижі, є важливими джерелами для поиуку бібліографічної інформаиії про П'єра Ріко де Тіррегая та його замовлення на проекти.

П'єр Ріко де Тірегей народився близько 1725 року у франиузькій дворянській родині в районі Тирегале в Провансі. Його професійна освіта була покращена в Барселоні під керівництвом інженера Френсіса Рікоде де Тьєрреагіла. На території Речі Посполитої він прачював з 1752 по 1762 рр. За чей час у їх діяльності можна виділити три періоди: IВариава (1752-1757), II - Львів (1757-1760) та III - Варшава (1760-1762). Більшість замовлень архітектор отримав від кількох магнатських родин: Браничьких, Поточьких, Мнішек та інших. Перша згадка про перебування П'єра Ріко де Тирегайла в Речі Посполитій відноситься до 1752 року, коли він отримав звання лейтенанта в піхотному полку великого коронного гетьмана Яна Клемента Браниџького (1689-1771) $і$ як військовий інженер вступив обслуговування. У портфоліо архітектора були включені: проект та керівничтво монтажними роботами з водопостачання саду та звіриния в місті Білосток, проект палаиу з садом у місті Кристинополь, палаи у селі Песпа, проект палаиу ЧацькихФелінських у Львові, проект модернізаиї̈ палаиу для Антонія Бєльського. Ймовірно, палачовий сад для греко-католииьких митрополитів у Львові та палач із садом у Краковиі - теж його робота. П’єр Ріко де Тірегей також склав детальний план міста Варшави в масштабі 1:1000 між 1762-1763.

Після дев'яти років служби П'єр Ріко де Тіррегей сподівався на підвищення. У грудні 1761 року він попросив гетьмана Браниџького допомогти йому просунутися до звання колони. Його прохання також підтримав маршал Ф. Бєлінський, який попросив гетьмана допомогти у Королівському дворі иим проханням, яке “надасть вариавському плану більше значення”, але, на жаль, це не спрачювало. Після одинадиятирічного перебування в Польщі, П'єр Ріко де Тирегей, не маючи можливості обіймати відповідну посаду при дворі Августа III, перейхав до Берліна в 1762-1763 рр., Де був призначений на інженерний факультет на невизначену посаду та викладацький склад посада при дворі прусського короля Фрідріха II. У 1772 р. У Потсдамі він опублікував нумізматичний трактат, присвячений російським медалям XVIII cm. У 1776 роиі П'єр Ріко де Тирегей отримав звання полковника і продовжує праиювати над наступним томом нумізматичного трактату про медалі Бранденбурзького суду, але незабаром він помирає.

Ключові слова: архітектор, П’єр Ріко де Тіррегей, палаи, сад, гідросистеми. 